\section{Dariusz Dziadosz}

Catholic University of Lublin, Lublin

dariuszdzi@op.pl

ORCID: 0000-0002-5191-0560

DOI: http://dx.doi.org/10.12775/BPTh.2018.023
Biblica

et

Patristica

Thoruniensia

11 (2018) 4: 463-493

ISSN (print) 1689-5150

ISSN (online) 2450-7059

\title{
The Spirit of YHWH as the Charism of the Pre-Monarchic Liberators of Israel and the Theological Symbol of God's Salvific Activity in the Book of Judges
}

\author{
Duch JHWH charyzmatem przedmonarchicznych \\ wyzwolicieli Izraela i teologicznym symbolem \\ zbawczej aktywności Boga w Księdze Sędziów
}

\begin{abstract}
One of the most characteristic and, at the same time, enigmatic formulas of the Book of Judges is syntagma rûh YHWH, regarded as one of the oldest forms of the Old Testament pneumatology, which attempts to express the spiritual character of the salvific presence and activity of God YHWH in the history of the chosen people. This formula is used by both the authors of the original sources about the pre-monarchic liberators of Israel (Judg. 13:1; 14:6,19; 15:14), as well as their Deuteronomistic redactors (Judg. $3: 10 ; 6: 34 ; 11: 29$ ) who relying on the theology of the Sinai covenant and the principles of God's retribution decided to reconstruct the era of judges. The article examines the origins and etymological and theological meaning of the Hebrew root rwh and the formula rûh YHWH, as well as the biblical concept of God's spirit in the broad context of ancient Middle Eastern literature and biblical traditions about judges.
\end{abstract}

Keywords: $r w h$; rûah YHWH; the spirit of YHWH; the Book of Judges; Othniel; Gideon; Jephthah; Samson.

Streszczenie. Jedną z najbardziej charakterystycznych, a zarazem enigmatycznych formuł Księgi Sędziów jest syntagma rûaḥ JHWH, która równocześnie zalicza się do najstarszych form starotestamentowej pneumatologii usiłującej wyrazić duchowy charakter zbawczej obecności i aktywności Boga JHWH w dziejach narodu wybranego. Tą formułą posługują się zarówno autorzy oryginalnych źródeł o przedmonarchicznych wyzwolicielach Izraela ( $\mathrm{Sdz} 13,1 ; 14,6.19 ; 15,14)$, jak też ich deuteronomistyczni redaktorzy (Sdz 3,10; 6,34; 11,29), którzy opierając się na teologii przymierza synajskiego i zasadach Bożej retrybucji, postanowili zrekonstruować epokę sędziów. Publikacja bada pochodzenie oraz etymologiczny i teologiczny sens hebrajskiego rdzenia rwh 
i formuły rûaḥ JHWH, a także biblijną koncepcję Bożego ducha w szerokim kontekście literatury starożytnego Bliskiego Wschodu oraz biblijnych tradycji o sędziach.

Słowa kluczowe: $r w h$; rûah JHWH; duch JHWH; Księga Sędziów; Otniel; Gedeon; Jefte; Samson.

The comprehensive reconstruction of the history of pre-monarchic Israel in Canaan proposed by the Deuteronomistic redactor of the Book of Judges, based on the sources available to him, refers to historical institutions and socio-religious realities from that period, but shows them in a specific perspective of theological interpretation of the history of the chosen people developed only after Babylonian slavery. ${ }^{1}$ The basis of this interpretation is the principle of God's retribution and the idea of salvific presence and fidelity to YHWH, in which the Deuteronomist incorporates the truth about the religious apostasy of the Israelites, the oppression provoked by it, and the unique concept of the leader (judge) remaining under the permanent or temporary influence of the spirit of YHWH (rîh YHWH). The concept of the spirit of YHWH appears in several books of the Hebrew Bible and acquires a different meaning depending on the literary and theological context in which it was written. Most often, this idea appears in the Deuteronomistic historiography of Israel (Josh-2 Kings), ${ }^{2}$ in which it gains quite diverse and sometimes enigmatic and controversial significance. From a theological perspective, most intriguing texts in this matter are messages about rûah-rä' "evil spirit (sent by YHWH)" (Judg. 9:23; 1 Sm. 16:14-16,23; 18:10; 19:9) or rûah šeqer "the spirit of lies" put by YHWH into the mouths of Ahab's prophets (1 Kings 22:21-24). The traditions of the spirit of YHWH recorded in the cycle of judges (Judg. 3:7-16:31) are also very interesting from the perspective of the Old Testament theology and the socio-religious profile of Israel. The exceptional nature and importance

1 According to the redactor of the book, the most important institutions of this period are theocratic model of power and YHWH rite associated with it (1:1-2,9; 20:1-48; cf. Josh 1:1-18), offices: judge - liberator, judge - administrator $(3: 7-16,31)$, prophet $(4: 5-7$; $6: 7-10)$, priest - Levite $(17: 7-13 ; 18: 3-6,15-20 ; 19: 1-30)$, the rite of YHWH war $(6: 11-7: 22$; $11: 30-40)$, the cult of YHWH and idolatrous worship of other gods $(2: 11-15 ; 3: 7,12 ; 4: 1$; $6: 1 ; 8: 24-27 ; 9: 4 ; 13: 1 ; 17: 1-13 ; 18: 3-31)$, religious covenant of Israel with God $(6: 8-10)$ and various forms of socio-political and religious interdependence within the generational structures of Israel (6:8-10; 9:1-6; 10:1-16).

2 The frequency of using rûah YHWH and rûah 'ẹlōhîm formulas in the Deuteronomistic historiography is high (25 texts); it is not so frequently repeated in other collections of biblical books. In the Book of Judges the phrase rûah YHWH appears 7 times $(3: 10 ; 6: 34$; $11: 29 ; 13: 25 ; 14: 6,19 ; 15: 14)$ and in this respect it might be compared only to the Books of Samuel where this syntagma appears 13 times. 
of these traditions are determined by their large number, diverse origins, as well as literary and theological originality suggesting a unique and complex cultural, religious and social context in which they had functioned before they were incorporated in the current structure of the book.

The aim of the article is to determine the current literary and historicosalvific profile, in which the rûh YHWH syntagma functions in narratives about judges (šoptîm). Firstly, its semantic field will be shown in biblical and extra-biblical sources. The content of the next stage of research will determine the theological foundations of the Deuteronomistic vision of the era of judges, especially the concept of the salvific presence of YHWH against the religious apostasy of Israel, which the redactor of the book presents in a two-stage introduction $(1: 1-34 ; 2: 1-3,6)$ and in the introductions to subsequent traditions of the major judges in 3:7-16:31. The final stage of analysis will present the source texts from the Book of Judges, in which the rûh YHWH formula (3:10; $6: 34 ; 11: 29 ; 13: 25 ; 14: 6,19 ; 15: 14)$ appears. It illustrates the nature and manner of God's influence on Israeli leaders in the pre-monarchic era. The exegetictheological analysis of source material about judges will be conducted according to the criteria of the comparative and historical-critical methods, which are still a key research tool for the Old Testament history books.

\section{Etymological and theological sense of rûah and rûah YHWH in the Hebrew Bible}

The original form of the Hebrew notion rûah has been probably developed relying on the onomatopoeia ${ }^{3}$ from the bi-consonantal root $r h,{ }^{4}$ but in its current form it is based on the three-consonant cluster $r w h$, which also occurs in the Aramaic language and the family of West Semitic dialects. In determining the semantic field of $r w h$, the Middle Eastern literature is helpful, as it includes synonymous terminology. This combination allows to discover the origin of the biblical rûah and sheds light on the theological sense of the spirit of YHWH in the Hebrew Bible. For example, in the Ugaritic texts about Baal-Hadad (storm god) the root $r h$ is used to describe the violent meteorological phenomena which accompany the descent of this god to the underworld, or to show Baal as a rider mounting the clouds ( $\left.r k b^{\prime} r p t\right)$ or being lifted on the wings of the

3 From the point of view of grammar this is gerund illustrating the idea of "wind blowing" or the process of inhaling and exhaling of air by a human being. S. Tengström, rûah, pp. 367-368; R. Albertz, C. Westermann, rûah, spirit, p. 1202.

\footnotetext{
4 W. Gesenius, E. Kautsch, Hebräische Grammatik, \$30g.h.k.
} 
wind (cf. Ps 18:11, 104:3). ${ }^{5}$ Describing the death of the deity of Akhat, another Ugaritic epic uses the root $r h$ to compare his departure to the last breath. ${ }^{6}$ The root $r w h$ appears in the Sumerian texts, which define Enlil as the "lord of the air," i.e. the god of wind and air. Sumerians thought that Enlil using these invisible elements sustained plant vegetation and human life, but also wreaked destruction, for example, ravaging the city of Ur. ${ }^{7}$ The theological point of reference for the Hebrew rûah may also be the Akkadian šăru "wind, storm, breath of god or life". The Babylonian Marduk was, for example, considered to be ili ša $\bar{r} i$ țābi "the god of good breath / breathing /which gives relief to the suffering (The Enûma Eliš VII, 23). ${ }^{8}$ The opposite of this "good wind, air, breath" emitted by Marduk was šâru limnu, the "wind of evil," which was used in Akkadian and Sumerian literatures by seven demons causing disasters and diseases. ${ }^{9}$ Another god of wind, the Egyptian Amon (Amun) "hidden, invisible" - the god belonging to the pantheon of eight primal deities of Hermopolis (in Thebes identified with the god of the sun Re: Amon-Re) made the land, animals and people fertile. In Egyptian mythology air and wind were cosmic manifestations of life and the breath of gods which gave or took away human life. ${ }^{10}$ This theological issue which was common to the Middle East and possessed similar terminology is reflected in the biblical texts on the origin (Job 33:4), ${ }^{11}$ the status of human life (Job 32:8) and the way God interacts with selected heroes of Israel (Ezra 1:1; Ps 76:13; Ezek. 3:12,24; 11:1). ${ }^{12}$

5 Die keilalphabetischen Texte aus Ugarit, I, 5; V, 7.

6 Die keilalphabetischen Texte aus Ugarit, I, 18; IV, 24-25.

7 A. Falkenstein, W. von Soden, Sumerische Hymnen, p. 200; S. Tengström, rûah, p. 369.

8 Marduk uses the wind and the storm in the fight against Tiamat and reserves for himself the power over these elements in the pantheon of gods (The Enûma Eliš IV, 45; V, 49-51), admitting only Baal-Hadad to her.

9 The biblical analogy for this theological concept is the image of God who sends his spirit (rûah YHWH) to Israel's judges $(3: 10 ; 6: 34 ; 11: 29)$, and the evil spirit to their opponents (rûah-rā' $\hat{a}$ mè'êt YHWH) (9:23-24). A similar situation takes place in the history of Saul and David, competing for power (see 1Sm 16:13 and 16:14-16).

10 S. Morenz, Gott und Mensch, p. 225.

11 The Yahwist source of Gen 2;4a-25, which says that YHWH: wajjippah be'appājw nišmat hajjîm "breathed in his [man's] nostrils the breath of life"(Gen 2:7) deserves particular attention.

12 D. Block, Empowered by the Spirit, pp. 42-54. 
The root $r w h$ appears in the Hebrew Bible in a verb form, ${ }^{13}$ but frequently it appears as a noun: rûah (378 times and in the Aramaic section of the Book of Daniel 11 times), ${ }^{14}$ demonstrating a rich variety of theological meanings. The concept of rûh has a long history in biblical literature, which is testified by 47 collocations in the original source text, which later was incorporated into the structure of the books of earlier prophets developed by the Deuteronomistic circles (Josh-2 Kings). ${ }^{15}$ Ruah rarely appears in the Pentateuch, where it usually signifies wind (Gen 8:1; Ex 10:13,19), the breath (life) of man or the state or abilities of the human spirit (Gen 6:17; 7:15,22; 26:35; 45:27; Ex 6:9; 28:3; Num $5: 14 ; 14: 24 ; 27: 18) .{ }^{16}$ It is omitted by the redactors of the Book of Leviticus, and Deuteronomistic theology notes it only in Deut 34:9. Some prophetic texts show interest in this term (Isa 51 times, Neh 18 times, Ezra 52 times, Hos 7 times, Zech 9 times), ${ }^{17}$ wisdom books and poetry (Ps 39 times, Job 31 times, Prov. 21 times, Eccles 24 times). ${ }^{18}$ The Hebrew Bible usually includes

13 Here there are the most important of its meanings: "to smell” (Deut 4:28; Ex 30:38), "to feel relief" (1Sm 16:23; Job 32:20), "to be spacious, vast" (Jer 22:14), "inspire, take pleasure in" (Isa. 11:3). P. Reymond, rwh̆, p. 386. An Akkadian napāšu has a similar semantic field, the meaning of which oscillates between "blowing, breathing" and "spreading".

14 J. Dunn, Spirit, Holy Spirt, p. 1125; S. Tengström, rûaḥ, p. 372.

15 Most often, the notion of rûh appears in the Book of Judges (8 times), 1 Samuel (16 times) and in the series of traditions about Elijah and Elisha (1Kings 17-2Kings 9) (9 times). In other Books of the Josh-2Kings collection, rûah appears twice in the Book of Joshua $(2: 11 ; 5: 1)$, three times in 2 Samuel $(22: 11,16 ; 23: 2)$ and once in 1 Kings $10: 5$ and 2 Kings 19:7.

16 In the Pentateuch, rûah rarely appears with regard to God. There is one example where it defines the powerful presence and activity of the Creator preceding the creation of the world (Gen 1:2). It defines several times divine origin of wisdom, leadership experience and practical skills of biblical heroes (Gen 41:38; Ex 31:3; 35:31; Deut 34: 9) and it is considered to be the source of prophetic oracles (Num 24:2).

17 The earliest prophets rarely refer to the theological concept of the spirit of YHWH. Amos speaks of YHWH as the windmaker (4:13), and Isaiah mentions the spirit of YHWH in reference to messianic promises (11:2). This text of Isaiah is seen as a late gloss, the final fulfillment of which, is the tradition of Jesus - the Son of God: possessed by the Spirit sent by the Father (Mt 3:16-17; Mk 1:10-11; Luke 3:22). Hosea sees the spirit of YHWH as the weapon of God's wrath towards the unfaithful Ephraim (13:15; cf. Mic. 2:7), and Micah recalls him in the perspective of the prophet's mission (3:8; cf. 2:11). In most of Jeremiah's 18 texts, rûh signifies the wind which is an instrument of judgment and wrath of YHWH. The idea of the spirit of YHWH is more often used by prophets after Babylonian captivity (Ezek 52 times, Deutero- and Trito-Isa 23 times) and during the Second Temple period (e.g. Zech 9 times, Hag. 4 times, Mal. 3 times).

18 In the Book of Kohelet, the term rûah is usually understood as "vanity, something fleeting" $(1: 6,14,17 ; 2: 11,17,26$; etc). 
rûah in one of the following semantic categories and interprets as: 1) a meteorological phenomenon "wind, whirlwind, air, atmosphere" understood as an unpredictable and invisible element created by God and used by Him as a tool of power, anger, punishment, but also liberation (Gen. 1:2; 8:1; Ex 10:19; Num 11:31; 1 Kings 18:45; 2 Kings 3:17; Ps 48:8; Is 59:19; Jer 2:24; 18:17); ${ }^{19}$ 2) the definition of place and direction, e.g. the phrase "to the four winds" means "to all parts of the world; all directions" (Jer 49:36, Ezek 5:10-12, 17:21, Dan 7:2); 3) a symbol (image) of the disposition, attitude, tendency, character of a human or social group, e.g. phrases: mōrat (qōṣer) rûah "bitter (short) spirit" or sārâ rûah "restless, miserable soul" express strong human emotions and feelings, such as anger, spite, worry, bitterness, excitement, despondency, fear, impatience, and even insurmountable depression (Gen 26:35; Ex 6:9; Ezek 3:14; Josh $2: 11 ; 5: 1$; 1 Kings $21: 5$; Is 19:3); 4) the process of breathing (see $n^{e} \bar{s} a \bar{m} \hat{a}$ "breath" in Gen. 2:7) understood as the activity that sustains the vital functions of man and of living creatures and the basis of their life which is the gift of the Creator (Gen 6:17; Job 12:10; 27:3; Ps 104:29, Ezek 37:5-14); ${ }^{20}$ 5) a habitat of cognition, will and skill (a synonym of Hebrew "heart"), which determines the quality of human thoughts, feelings and decisions, and is the source of his intellectual and manual abilities (Ex 28:3; 31:3; 35:31; Isa 29:24). ${ }^{21}$

In the Hebrew Bible, the term rûh acquires a deep theological meaning in the formulas referring to God: rûah-'èl ('êlōhîm) "the spirit of God" (11 times), rûah YHWH "spirit of YHWH" (25 times) and rûah qodšo "the spirit of His holiness" (Ps. 51:13, Isa 63:10,11). Some of these formulas refer to the original meaning of the concept of rûah "wind", showing this meteorological phenomenon as a tool of God's action (Isa 40:7; 59:19; Hos 13:15). Others are the resultant of its two basic meanings: "wind" and "spirit", describing, for example, the process of divine transfer of prophets (1 Kings 18:12; 2 Kings 2:16; Ezek 37:1). Still, others depict emotions (e.g. anger, impatience) or unsurpassed wisdom (mysterious personality) of God (Mic 2:7; Isa 40:13). The Spirit of God is linked with the creation of the world (Gen 1:2; Job 33:4), its restoration after the flood (Gen 8:1), and also with the call to existence - i.e. the liberation of Israel by means of a wind (Ex 14:21-22; 15:10) and the Church (Acts 2:1-4). Syntagma "the spirit of YHWH" is sometimes treated in the Hebrew

19 P. Reymond, rûah, p. 387; F. Scerbo, rûah̆, p. 345;

20 In this sense, the biblical texts also refer rûah to God: "the breath of His nostrils" (wind?). This anthropomorphism is an illustration of YHWH's powerful might and punishing wrath (Ex 15:8; 2 Sm 22:16; Job 4,9; Isa 40:7).

21 M. Van Pelt, W. Kaiser, D. Block, rûaḥ, pp. 1073-1076; S. Tengström, rûah, pp. 376-377. 
Bible as an emanation and manifestation of omnipresence, omnipotence and transcendence of God, and even His alter ego (Ps 139:7, Isa 40:13). In this theological context, it appears in the oldest biblical sources - including the Deuteronomistic historiography of Israel where it serves to show God's power and might over the world and its inhabitants, and, above all, to depict the salvific activity of YHWH whose addressees are Israelis and their socio-religious leaders. In the source material developed by Deuteronomistic circles, the "spirit of YHWH" is associated with the charismatic (liberating and administrative) mission of judges and kings (Judg. 3:10; 6:34; 9:23; 11:29; 13:25; 14:6,19; 15:14; 1 Sm 10:6,10; 11:6; 16:13-16; 19:20,23; $2 \mathrm{Sm} \mathrm{23:2),} \mathrm{and} \mathrm{also} \mathrm{with} \mathrm{the} \mathrm{institution}$ of the prophet ${ }^{22}$ in various areas of its public activity in Israel.

In the Book of Judges, rûah appears eight times, always in a direct relation to the presence and activity of God, who wants to restore the shattered socio-religious and moral order in Israel $(3: 10 ; 6: 34 ; 9: 23 ; 11: 29 ; 13: 25$; $14: 6,19 ; 15: 14)$. It is associated seven times with the name of the God of Israel: rûah-YHWH $(3: 10 ; 6: 34 ; 11: 29 ; 13: 25 ; 14: 6,19 ; 15: 14)$, and once it creates a construct with the adjectival attribute $r \bar{a}{ }^{\prime} \hat{a}$ "evil", but in this case it refers to God, defining the "evil spirit" which was sent by Him to cause an argument between Abimelech and the elders of Shechem (9:23). An important conclusion that emerges from the analysis of texts on judges is the close relationship between the word rûh and syntagma of rûh YHWH with the context of war (the institution of YHWH war) and military and socio-political activity conducted in the atmosphere of oppression of the Israelites. The formula rûa YHWH most often appears in the Samson cycle $(13: 25 ; 14: 6,19 ; 15: 14)$, and it is also present in the narratives of Othniel (3:10), Gideon (6:34) and Jephthah (11:29). Moreover, the notion of rûh appears only in the theological key in the book, showing the manner and circumstances of God's influence on the chosen leaders of Israel. After a cursory reading of their current context, it can be observed that the interference of the spirit of YHWH always happens in a close correlation with the salvific will of the God of Israel towards the oppressed people and a liberating mission of a judge. It usually took the form of a sudden and spectacular interference of God in the life of a local leader and was oriented to improve the existential situation in which the Israelites subordinated to him were placed. In the Hebrew Bible, the "spirit of YHWH" formula is applied only to the God of Israel, and in the Book of Judges it describes the idea of God's direct interference in the life of a chosen man, which takes place through a trial

22 Some texts define the prophet directly as "a man of spirit (inspired by the spirit) of YHWH” (Num 11:17,25; 1 Sm 10:5-6,10-12; 19:20,23; 1 Kings 18:12; 2 Kings 2:16; Ezek $2: 2 ; 3: 12,14 ; 8: 3 ; 11: 24 ; 37: 1)$. 
(Samson) or a one-off act (Othniel, Gideon, Jephthah) and relies on giving him effective help, invincible (supernatural) internal and external strength enabling victory over the enemy and freeing all Israel.

And here are the most important conclusions of this etymological summary. The activity of the spirit of YHWH in the texts on judges has been inscribed in the climate of socio-military activities, but the terminology expressing it is too enigmatic and does not allow to provide an unambiguous definition. In order to properly determine the semantic field of YHWH's rûah, it is necessary to focus first on the physical properties of one of the most powerful elements - the wind (rûh), which in the Bible is considered as a natural phenomenon under the power of the Creator and provokes positive or negative effects. Therefore the effects of the spirit of YHWH on judges and their enemies can be compared to the situation caused by the impact of a powerful wind that ravages and destroys the obstacles on its way. To define the meaning of rûa YHWH, the context of human life must be taken into account. Its fundamental manifestation and symbol is breath, which also bears a semantic relation to rûh. In narratives about judges rûa YHWH communicates the idea of variously endangered life and the necessity of saving or renewing it, both in the individual dimension (see the theme of personal oppression, rejection and danger in the relationship of Gideon, Jephthah and Samson) and collective (the fate of the oppressed and humiliated people). The term rûah assigned to the name YHWH also acquires a transcendental, sacred and theological dimension, indicating the supernatural qualities of God's action, and even the attributes of His person who, permanently or temporarily, affect the attitude of the deliverer. Describing the spirit of YHWH, the redactors of the book communicate, above all, the idea of the gift of great courage, strategic experience, superhuman physical strength, socio-political wisdom and military authority, which have been given to judges for effective and uncompromising action towards YHWH and Israel. The book also informs that the effects of the activity of God's spirit ${ }^{23}$ can bear a destructive and hostile character. His action, however, never breaks the order of law established by God and is not a manifestation of evil in a moral sense. On the contrary, it is inscribed in the biblical rule of retribution, which regulates God's

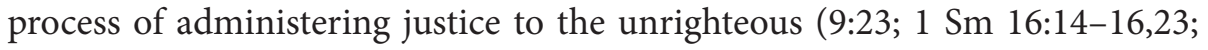
18:10; 19:9; cf. 1 Kings 22:23-24).

This is the most important information about the etymology and meaning of rûah YHWH in different contexts of the Hebrew Bible, which will help to de-

23 In Josh-2 Kings this type of spirit of YHWH is called rûah-rā' $\hat{a}$ "evil spirit" [sent by YHWH]" (9:23; 1 Sm 16:14-16:20; 18:10; 19:9). Neh 9:20 speaks of a good spirit rûah tôb, which helps in teaching the people. 
termine the precise theological sense of the formula in the narratives on judges. Biblical sources differently describe the influence of the spirit of YHWH on the leaders of Israel. The proof of this is the following range of verb forms, with the help of which the activity of God's spirit is determined in the books of Josh-2 Kings, the work of the Chronicler and other sources of the Old Testament: șlh 'al "to act with force, with impetus, to move, to penetrate, to impel, to impose, to commit to act, to ensure success" (14:6,19; 15:14, see 1 Sm 10:6,10; 11:16; 16:13; $18: 10) ; l b s ̌$ " to clothe, to dress, to put on" (6:34; see 1 Chron. 12:19; 2 Chron. 24:20); $p$ ' $m$ " to urge, to push, to compel, to persuade, to interrupt" (13:25); hjh 'al "to be, to remain above" (3:10; 11:29; cf. Num 24:2; 1 Sm 16:16,23; 19:20,23; 2 Chron and 15:1;20:14); swr min 'al "to cease (to leave someone alone), to abandon (to leave without help)" (14:20; 1 Sm 16:23; 18:12; 28:15-16). For a complete overview of this terminology, the expression $n \mathrm{pl}$ 'al "to fall, to fall on, to take control of someone, to control someone" (Ezek 11:5), which does not appear in the Deuteronomistic historiography, should be added.

\section{Deuteronomistic concept of the activity of YHWH in the period of judges according to Judg. 1:1-3:6}

A detailed analysis of the literary and theological context in which rûa YHWH appears in the Book of Judges should be preceded by the evaluation of the sources of Israel's liberators and administrators, which were collected and ordered by the circles of Deuteronomists in the course of its multi-stage process of redaction. The preliminary reading of the book suggests that it is a carefully prepared collection of different traditions, which has a clear theological profile and a transparent and symmetrical structure based on three thematically related elements: a two-stage introduction (1:1-3:6), a body of twelve messages about the judges (3:7-16:31) and a two-stage conclusion (17:1-18:31; 19:1-21:25). The pre-monarchic history of the Israelites in Canaan described in these narrative segments initiates an alternative to Josh 1:1-21:45 vision of the conquest of Canaan (1:1-36), and ends with a description of the fratricidal war caused by the crime of the inhabitants of Gibeah (19:1-21:25). Both parts postulate the need for systemic and cultural-religious changes in Israel, which is most visible in $17: 6 ; 18: 1 ; 19: 1 ; 21: 25$. The narrative framework includes colorful sources about local commanders (šoptîm), who wielded power over individual clans or confederations of related generations ${ }^{24}$ between Joshua's military activity

24 The sources about 12 judges collected in 3:7-16:31 are of different length: from summaries from one to several verses in length about minor judges $(3: 31 ; 10: 1-5 ; 12: 8-15)$ to 
in Canaan (Josh 1:1-Judg. 2:10) and the establishment of a monarchy (1Sm 7:2-12:25). ${ }^{25}$ Within the 3:7-16:31 cycle, all formulas with the spirit of YHWH $(3: 10 ; 6: 34 ; 11: 29 ; 13: 25 ; 14: 6,19 ; 15: 14)$ are included, but this does not mean that they originate from one source and fulfill an identical role in the current theological and narrative structure of the book. The terminological and cultural-religious differences in describing the influence of the spirit of YHWH on the judge present in these texts suggest a different origin of these formulas, which can be determined only after a detailed literary and exegetic-theological examination of each of the passages. To make this research reliable, it is first necessary to know the general historical and salvific context of pre-monarchic Israel, in which Deuteronomists have inscribed sources about judges. The image of this era, and in particular the concept of the relationship between God and Israel, is presented in two complementary thematic parts of the introduction to the book $(1: 1-2: 10 ; 2: 11-3: 6)$, as it is the key to the theological reading of 3:7-16:31 and the rûa YHWH formulas which are present in the text.

The main goal of the redactors of 1:1-3:6 was to provide reasons for the military and socio-economic failures which after the death of Joshua befell the Hebrew families settled in Canaan. According to a historico-salvific perspective of events promoted by them, a key criterion for evaluation and constant point of reference in the presentation of this unfavorable situation was the repeated breaking of the covenant with $\mathrm{YHWH}$, which Israelites provoked since

extensive narratives resembling military sagas, full of religious folklore (6:1-9:57; 10:6-12:7; 13:1-16:31). These traditions are in the form of a narrative prose, although there are also poetic compositions (5:1-31a; $9: 7 b-15)$. Both types of texts bear traces of many literary and theological interferences, thanks to which the original messages about local heroes obtained a richer form and content. The oldest sources (oral tradition may even date back to the epoch they describe, and the earliest ones originate from the post-Deuteronomistic period of the edition of the book (the Persian era). The most important contribution to the current version of these texts is the Deuteronomistic environment, which successively incorporated the original traditions about judges into the pan-Israeli theology (12 leaders ruling in the whole Israel), the idea of YHWH's war, the principles of God's retribution and the covenant with YHWH. B. Lindars, Gideon and Kingship, pp. 315-316; H. Haag, Gideon - Jerubbaal Abimelek, pp. 305-314; S. Gillmayr-Bucher, Memories Laid to Rest, pp. 115-132; Y. Amit, Who Was Interested in the Book of Judges?, pp. 103-114; R. Person, The Deuteronomic School, pp. 119-120.

25 Apart from 12 local Israeli leaders appearing in 3:7-16:31, the Hebrew Bible attributes the title of judge to Eli and Samuel (1Sm 4:18; 7:10-12:17; 12:11). W. Richter, Zu den Richtern Israels, pp. 61-68; A. Steinmann, The Mysterious Numbers of the Book of Judges, pp. 491-500. 
the time of Moses. ${ }^{26}$ Hence the religious apostasy of Israel was declared in the first Josh-2 Kings as the reason for the bloody battles of Canaan and oppression of the Hebrew generations in the period of the Judges, it then became the reason for the Assyrian and Babylonian captivity (2 Kings 17:7-23; 24:8-20). This theological re-reading of history was based on the idea of God's retribution resulting from the covenant of Israel with YHWH. Its essence, which was regularly reminded by Moses and Joshua (Ex 19:1-24:18; Deut 27:1-28:69; Josh 23:1-24:28), was the attitude to God's law, exclusive worship of YHWH, the prohibition of worshiping other gods and the distance to the polytheistic civilizations of the peoples of Syro-Palestine (2:1-3). Only faithfulness to YHWH guaranteed the continuation of victories initiated by Joshua and the defense of lands conquered in Canaan, which God promised to the patriarchs (Gen $12: 7 ; 13: 14-17 ; 15: 7-21 ; 28: 13$ ) and gave to the son of Nun ( Josh 1:1-9, 21:4345). The successor of Moses knew that the power of YHWH crushes the power of opponents and guarantees success in battle, hence - what the Deuteronomist strongly emphasizes in Josh $1: 1-18 ; 7: 6-26 ; 22: 1-24: 31$ - throughout the period of ruling he faithfully guarded the principles of the covenant, enjoying God's support in confrontation with the peoples of Canaan. The situation in Israel changed dramatically after his death mentioned in 2:10. The demise of the leader who throughout his life had been obedient to the will of YHWH which was revealed to him (Josh 1:1-18) and true socio-religious heritage of Moses led to almost immediate abandonment of the rule of previously cultivated theocracy (Ex 19:1-24:18; Deut 27:1-28; 69, Josh 23:1-24:28), ${ }^{27}$ and consequently, to the painful loss of God's blessing and a series of military failures.

To illustrate the new realities of the era of judges, the Deuteronomist - on the basis of a theological retrospection - incorporated two periods of the history of pre-monarchic Israel (1:1-2:7 and 2,9-10) between two formulas of the

26 In the reconstruction of the history of Israel proposed in Josh-2Kings, the era of judges functions as a theological paradigm that predicts the Assyrian and Babylonian slavery and at the same time justifies it relying on the convention of the Sinai Covenant present in Deuteronomic (Deut 4:1-40; 9:1-29; 11:1-32; 26:16-30:20) and Deuteronomistic theology (Josh 1:1-9; 21:43-45; Judg. 2:11-23; 1 Kings 2:1-4; 6:12-13; 2 Kings 17:7-23; $22: 15-20 ; 24: 13-16: 20)$.

27 From the perspective of Deut 24:29-31 and other deuteronomic passages (see the meaning of the ( $l$ '-) $j d$ ' ' $t$-YHWH formula "(not) know YHWH" in Deut $11: 2 ; 31: 13 ; 34: 10$ ) the Deuteronomist in Judg. 2:10 criticizes the behavior of the generation of the Israelites born after the death of Joshua and the attitude of the still living eyewitnesses (zeqeinim "elders") of the acts of YHWH during the lifetime of Moses and the son of Nun. He believes that the cause of all Israel's defeats in the pre-monarchic era is their disbelief and disregard for the salvific presence of God. 
death of Joshua $(1: 1 ; 2: 8)$. The first period is the new stage of the conquest of Canaan, which is carried out according to different rules and with a different effect than the campaign described in Josh 1:1-21:42. ${ }^{28}$ The second is the period of the religious apostasy of the Israelites, which results in the collapse of intergenerational socio-military structures and the cyclical loss of freedom assessed as God's punishment. The 1:1-3:6 complex composed of a variety of editorial material has the shape of a declaration text which, relying on the truth about God's justice and mercy, depicts the historico-salvific realities of the era of judges, and at the same time, provides the background for the presentation of 12 Israeli leaders in 3:7-16:31. This theological paradigm has the greatest impact on the profile of the tradition of the major judges, it also creates a background for the recurring synagma of rûah YHWH (3:10; 6:34; $11: 29 ; 13: 25 ; 14: 6,19 ; 15: 14)$. Its characteristic feature is a model of the conquest of Canaan, which is different from the account in the Book of Joshua, according to which only the coalition of Judah and Simeon (1:3-20) and the lineage of Joseph (1:20-26) are successful. ${ }^{29}$ The remaining clans must accept the difficult conditions of peaceful coexistence with the native people of Canaan and be satisfied with the status of the ethnic minority, which could only inhabit unattractive areas or - like the Dan family - be deprived of their own

28 According to the majority of exegetes, the reconstruction of the struggles for Canaan and the list of territorial acquisitions in 1:1-36 are more historically credible than their theocratic vision in the Book of Joshua. Both versions were born in a Deuteronomistic environment, but there are different theological and ideological aims behind them, hence their wide divergence. The redactor of the Book of Joshua decided to show the conquest of Canaan through the prism of theocracy and fulfillment of God's promises revealed in the Torah, which is why he perceives the territorial gains of the Israelites from the perspective of the reign of King David. The editor of Judg. 1:1-36, in turn, assesses these facts from the perspective of the collapse of the monarchy of Israel and Judah, and the Assyrian and Babylonian slavery. His reconstruction of the conquest of Canaan is restrained ideologically and rooted in historical realities (the conquest is based on armed struggles and peaceful infiltrations). From this hermeneutic perspective, the lack of territorial gains after the death of Joshua is seen as God's punishment and already at this stage of the historiography Josh-2 Kings announces the temporary loss of the promised land after 722 and 586 AD.

29 The kindness of YHWH for these generations (see the formula of vajje hî YHWH't "and YHWH was with" in 1:19a, 22b) is a recurring motif of the Hebrew Bible because it is visible in Josh-2Kings, the last passages of the Torah (Gen. 48:8-20; 49:8-12) and prophetic traditions (Ezek 37:15-28). God's support for Judah and Joseph (Ephraim), on the one hand, explains why these two families have gained key lands in Canaan, the strongest socio-political position among Hebrew generations and built structures of the monarchy, and, on the other hand, defines the genesis of their rivalry $(1: 1-26,28-29 ; 8: 11-3 ; 12: 1-6$; cf. 2Sm 7; 1Kings11-2Kings 25). A. Mayes, Israel in the Period of the Judges, pp. 106-107; D. Block, Judges, p. 102; Y. Aharoni, New Aspects of the Israelite Occupation, pp. 254-267. 
land $(1: 34 ; 17: 1-18: 31)$. The reason why YHWH limited the support for the Israelites was their religious infidelity $(2: 2 b)$, which - according to the chronology of the book (see the layout of the material in 1:1-2:10 and 2:11-3:6) - they committed already in the first generation after the death of Nun's son and continued in subsequent generations. Justice and, on the other hand, faithfulness and mercy of YHWH determined that in this period God showed His salvific presence only to two chosen families $(1: 19 a, 22)$. YHWH interferes only by the Messenger (2:1-5) in the history of all generations in the first part of the book (1:1 -2:10), but the character of this angelophany is extremely negative. The oracle of YHWH draws the context of the Israelites' defeat in Canaan after Joshua's death (1:1-36), but, above all, predicts a period of fierce confrontation with the Syro-Palestinian peoples, which will provoke oppression and slavery until the royal rule of Saul and David (1 Sm 9:1 -2Sm 5:25).

The Deuteronomist speaks about this period in the second part of the introduction (2:11-3:6), ${ }^{30}$ also in a clear theological perspective oscillating between the idea of YHWH's anger and the truth about His faithfulness and constant mercy that cannot be destroyed even by periodic religious apostasies. This optics is best seen in the summary 2:11-23 - where God is the most frequent subject of verbal forms $(2: 12,14,15,16,18,20-22,23)$ and the protagonist of the events described - and in each of the six consecutive traditions of the major judges $(3: 7-30 ; 4: 1-9: 57 ; 10: 6-21: 7 ; 13: 1-16: 31) .{ }^{31}$ The text $2: 11-23$ describes the relationship between the Israelites and YHWH during the period of judges which, according to the Deuteronomist, determined the serious crisis of theocratic structures and radical changes of the military, socio-political and cultural-religious status of the Israelites in Canaan after Joshua's death (1:1, 2:7-10). The pericope, $2: 11-23$, and all accounts about the major judges $(3: 7,12 ; 4: 1 ; 6: 1$; $8: 33 ; 10: 6 ; 13: 1)$ begin with the information about the religious apostasy of the Israelites from YHWH, which was manifested in a cult of the gods of Syro-Pal-

30 The current form of this section is an editorial compilation of two independent traditions created within the Deuteronomistic environment $(2: 11-23 ; 3: 1-6)$, which explain in different ways Israel's failures in the struggle for Canaan, and at the same time offer a precise and appropriate approach to the interpretation of the sources about Israeli leaders (3:7-16:31) and the crisis of its socio-religious structures on the eve of the establishment of the monarchy (17:1-21:25).

31 God's influence on the era of judges can also be seen in the oracle of YHWH cited in 2:20b-22 (cf. 2:1b-3) by the Deuteronomist. However, God's activity in section 1:1-3:6 is never expressed by the syntagma of rûh YHWH, which suggests its non-Deuteronomistic origin. 
estine. ${ }^{32}$ This information in the 2:11-23 initiates theological structural model, in which the redactor of the book has incorporated the sources about the major judges. Exegetes differently define the number, scope and theological meaning of the subsequent components of this model, but they agree that it best illustrates the Deuteronomistic concept of the salvific presence of God in the age liberators. This theological paradigm is based on the information about the unjustified apostasy of Israel, which results in the wrath of YHWH and the punishment in the form of a military invasion of a foreign army, leading to a brief or prolonged period of slavery and oppression. When the situation of the Israelites becomes unbearable, there is breakthrough in their attitude towards the God of fathers, which, however, except for the situation described in 10:10-16, does not bear any signs of conversion and departure from idolatrous practices, but is only a cry for help to YHWH dictated by faith in His power repeatedly demonstrated in the past. According to the Deuteronomistic vision of events, even this calculating and short-lived request of the Israelites evoked the answer of YHWH, and their oppression and humiliation aroused pity in Him and provoked immediate salvific interference $(2: 16 ; 3: 9,15 ; 4: 6-7 ; 6: 12,14,16 ; 10: 16)$. God chose, appropriately motivated and equipped successive leaders to lead the local generational coalitions, shed the yoke of the invaders from the Israelites and returned them their lost freedom and land. On the other hand, during military operations, God directed the military activity of the liberator and ensured him a victory in the battlefield, often by way of supernatural interference $(3: 10,28 ; 4: 15,23 ; 5: 4-5,2-23 ; 6: 9-15,22 ; 11: 30-33 ; 14: 19 ; 15: 14-17)$. Through

32 The most comprehensive catalog of foreign deities worshipped in Israel during the period of judges appears in the introduction to the story of Jephthah (10:6,10b,13-14). It also contains the only description in the book of the actual conversion and penitential rite of the Israelites (10:15-16). The apostasies of Israel in all these texts are expressed in the typical Deuteronomist terminology, which is visible in the concentric structure of the passage 2:11-13. In its center there is information that the Israelites wajjelk̂u 'ahărê 'élōhîm 'ăhêrîm mēélōhê hā'ammîm 'ǎšer sebîbôtêhem wajjištahăwû lāhem wajjak'isû 'et-JHWH "and they followed other gods of the peoples who surrounded them and worshiped them (literally - bowed in a gesture of prostration), which irritated (provoked wrath) of YHWH" (2:12b). This definition of apostasy, frequently repeated in the book, is surrounded by the similar verses 2:12a,13a, which inform that the Israelites ja 'azebû 'et-JHWH 'élōhê 'ábôtām "left YHWH - the God of their fathers", although He brought them from Egypt, and almost identical verses 2:11b,13b which inform about a strictly forbidden by God worship of Baal and Astarte: wajja 'abdî labba'al welā aštārôt "and served Baal and Astarte" (in 2:11b wajja 'abdîu 'et-habbe 'âlîm "and served Baal"). This chiastic reconstruction of events is preceded by 2:11, which defines apostasy as wajja ăšîu benê jiśrā'el 'et hāra 'be 'ênê JHWH "the Israelites did evil in the eyes of the Lord," which also opens every account about the major judge. P. Guillaume, Waiting for Josiah, p. 22; E. Knauf, Midian, p. 35. 
the activity of God and judges, the Israelites regained peace, and then - directly or indirectly - established military leaders as lifetime social and political administrators $(3: 11,30 ; 8: 22-23,28 ; 10: 2,3 ; 11: 1-11 ; 12: 7,8-9,11,13-14 ; 15: 20$, 16:31). Their power had a local scope, although the Deuteronomist presents this office in the pan-Israeli perspective (ruling in the whole Israel) and theocratic (concern for socio-military and religious order), ${ }^{33}$ so it must be assumed that it guaranteed stability and freedom only in the region controlled by the judge and only during his reign. His death resulted in another act of apostasy and, consequently, another punishment of God in the form of armed invasion and oppression from foreign peoples and the salvific re-intervention of $\mathrm{YHWH}$ caused by the dramatic situation of the Israelites. The cyclical panorama of the era of judges illustrates the historical background of the activities of the premonarchic leaders of Israel, but, above all, serves to show the real presence of YHWH in the history of Israel. This presence is manifested in the two complementary levels resulting from the Sinai Covenant: God's faithfulness and concern for the Israelites and God's justice, which rebukes every religious apostasy. This theological truth constitutes the foundation of the image of God in the Book of Judges and the concept of His presence in the history of Israel, which is characterized by texts about the influence of the spirit of YHWH on the liberators of the people.

\section{The Spirit of YHWH in the traditions of major judges}

To present the correct image of deuteronomistic pneumatology in the Book of Judges, it is necessary to conduct an analysis of the form, structure and literary context of the texts in which the expression rûh of YHWH appears. There are seven texts $(3: 10 ; 6: 34 ; 11: 29 ; 13: 25 ; 14: 6,19 ; 15: 14),{ }^{34}$ and their preliminary reading allows to divide them into two groups characterized by a related lit-

33 Such a conclusion can be drawn on the basis of the theological structure of the book which considers the invasion of foreign troops and oppression of Israel as the fruit of its religious apostasy and the period of peace as a result of God's salvific interference and the fruit of the judge's rule. By juxtaposing the source about Gideon who alone practiced idolatry before and after the liberating mission $(6: 26-32 ; 8: 24-27)$ provoking the fall of his family and the fratricidal war in Israel $(8: 27 b, 33-34)$ with the remaining sources, the Deuteronomist emphasizes that one of the significant tasks of the judge was to care for the monotheistic worship of YHWH resulting from the Sinai covenant (see Josh 1:1-9).

34 The expression rûă appears even in 9:23 in the formula rûah rā' $\hat{a}$ "the evil spirit," where it denotes the spirit of contention, which God used to break the coalition of Abimelech with the Sychemites and to justly punish their crime. 
erary and theological nature: the texts on Othniel (3:10), Gideon (6:34) and Jephthah (11:29), and the texts of Samson (13: 25; 14:6,19; 15:14). Looking for the theological meaning of the rûh YHWH formula, it is also necessary to determine the origin of the traditions to which it currently belongs and the manner in which their authors and redactors report and interpret the historical background of the era of judges. Due to the nature of the publication, this stage of research will be limited to the synthesis of key conclusions drawn from the exegetic and theological analysis of selected sources.

\subsection{The "spirit of YHWH" formula in the accounts on Othniel, Gideon and Jephthah}

The first reading of the traditions about the judges in which rûah YHWH occurs suggests that they are not homogeneous. The texts about Samson (13:25; $14: 6,19 ; 15: 14)$ should be examined using other criteria, as they are part of one set of traditions. They refer to one character, use related terminology and narrative style (religious folklore), and they describe and evaluate the action of the spirit of YHWH from the same theological perspective, focusing not on the situation of the oppressed Israel, but on the vicissitudes of the judge's life. The earlier traditions of the liberators, such as Othniel (3:10), Gideon (6:34) and Jephthah (11:29) present the rûh YHWH formula in a different narrative and theological view, which suggests its different genesis and role than in the Samson cycle. Each of these three narratives is characterized by the original form, literary structure and origin, as well as the function it performs in the current structure of accounts about the major judges (3:7-16:31). Even the preliminary reading suggests that in these texts the syntagma rûh $Y H W H$ is not a leading theme and does not decide about the literary and theological profile as much as in the account about Samson.

The narrative of Othniel (3:7-11) is the first tradition and also the shortest one in the book about the major judge. It consists of a fragmentary source material ${ }^{35}$ inscribed in a historico-salvific copy, in which the Deuteronomist incorporated all accounts about liberators. ${ }^{36}$ The summary about Othniel differs

35 The linguistic and theological analysis of 3:7-11 allows to find the traces of the original message in the information about the enemies of Israel, duration of oppression $(3: 8 b)$, personal details of the judge $(3: 9 b)$ and laconic reconstruction of the battle $(3: 10 \mathrm{~b})$, which in the oral tradition could have even reached the era of events described.

36 In Othniel's story, a Deuteronomistic scheme describing the oppression and liberation of the Israelites based on the principle of God's retribution and theology of the covenant (cf. 2:11-23) has been applied in a complete form. 
from five analogical traditions not only in the official and concise (chroniclelike) tone of the narrative, but also in the unique theological perspective promoting the pro-Judah interpretation of reported events ${ }^{37}$ and the truth about the multifaceted presence of God in the history of Israel. The formula emphasizing the influence of the spirit of YHWH on Othniel, despite being the central part of pericope (3:10a), is not the climax of its structure and does not carry the key theological message. This role is played by the Deuteronomistic phrase wajjittēn JHWH bejādô 'et, which documents the interference of YHWH in the course of the battle and the release of Chushan-Rishathaim in the hands of Othniel specifying who is the ultimate cause of the military success of the Israelites.

Determining the origin of the phrase watteĥ̀ 'älājw rûah-YHWH "the spirit of YHWH was above him" in 3:10 is not easy. The presence of the same or similar expressions in other places of Deuteronomistic historiography $(11: 29 ; 1 \mathrm{Sm} 19: 9,20,23 ; 2 \mathrm{Kr} 2: 15)$ suggests that this syntagma was not part of the original version of the source about Othniel, but was the result of its elaboration done by one of redactors of the book who literally and theologically developed and ordered accounts about judges in 3:7-16:31. Therefore it is difficult to establish the identity of this redactor relying on this tradition. Unlike most concepts in 3:7-11, the phrase watteĥ̀ 'ālājw rûah-YHWH does not belong to the Deuteronomistic terminological copy which defines God's activity in the era of judges, shown for the first time in 2:11-3:6. This means that its author who edited the theological structure of the book was not a Deuteronomist. ${ }^{38}$ According to similar criteria, the origin of the spirit of YHWH should be assessed in 6:34 $4^{39}$ and 11:29. The form and content of these glosses do not fit into the literary-theological profile of the original

37 Othniel, the son of Kenaz, a younger brother of Caleb, is not accidentally the first judge presented in the book. The Deuteronomist links Othniel with the tribe of Judah (1:1315) which gains priority among generations and exceptional support from God (1:1-2,19a). The pro-Judah redactor of the Book shows Othniel as the initiator of the process of Israeli liberation and he is also portrayed as the only judge without religious, social and moral prejudices.

38 The syntagma rûh-YHWH does not appear in the Book of Deuteronomy as a theological interpretation for a Deuteronomist. The term rûah appears only in Deut 34:9 (the expression rûah hokmâ "the spirit of wisdom"), defining the effects of putting hands by Moses on Joshua and handing over power to him on the eve of the conquest of Canaan.

39 Similar phrases, in which rûah or syntagma rûah-YHWH (rûah 'ẹlōhîm) occur in the structure with the verb $l b s$, appear in the work of the Chronicler, in which they describe the loyal and courageous attitude of Amasai - the military commander of David (1 Chron. 12:19), and the reformative activity of the priest Zechariah, the son of Jehoiada, against the unfaithful people of Israel (2 Chron. 24:20). 
military sagas of Gideon and Jephthah and it did not come from the pen of the Deuteronomist responsible for the first edition of the book and the content of 2:11-3:6. The author of these three glosses with the ruah-YHWH formula could have been the redactor of the original corpora of traditions about liberators (3:7-16:31), but it is more likely that he was one of the last Deuteronomistic redactors of the book or even its post-Deuteronomistic redactor. His aim was to incorporate the heroes chosen from 3:7-16:31 into a narrow group of the most notable liberators of Israel who were inspired by the spirit of YHWH. At the same time, the idea of the spirit of YHWH influencing the judges in the process of redeeming the Israelites served to remind him of the faithful and powerful love of God who shows pity to the chosen nation regardless of their cyclical treachery and worship of strange gods or the military power of the enemies.

According to the author(s) of the glosses containing the phrase rûa YHWH in 3:10; 6:23 and 11:29, Othniel was the first judge who in the situation of a military threat acted under the mandate of YHWH. Out of all liberators, he is the only one who is presented as a courageous and uncompromising fighter for land for the Israelites (cf. 1:12-15), the defender of the oppressed (3:9-10), and also as a model commander who does not violate the Mosaic law and ethical principles in his private life and in fight against the enemy. Although the summary of 3:7-11 does not speak explicitly about his moral and religious integrity, the comparison of Othniel to other judges leaves no doubt in this matter. Othniel is portrayed as a model of a military and socioreligious leader, and the gloss of YHWH's spirit supporting him is to confirm this assessment even more. The content and form of the phrase wattehî 'āläjw rûah-YHWH "the spirit of YHWH was above him" 40 indicate the supernatural source of the hero's special attitude, and a close relationship with the second part of the verse: wajjišpōt 'et-jiśrā'ēl "and exercised the authority of the judge in Israel" (3:10a) emphasizes the authority and theocratic dimension of his office. The syntax of verse 3:10 and the content of the immediate context suggest that the spirit of YHWH was not always with him, but was a temporary charism given by God for the good of the Israelites (cf. watteĥ̀ 'älājw and wajjišpōt 'et-jiśrá 'él). The chronological framework of the process of the influence of the

40 An analogical phrase wattehî 'al-jiptāh rûah JHWH"the spirit of JHWH came upon Jephthah" appears in 11:29, but the context of the narrative limits the influence of God to the process of recruitment of the army and armed struggle with the Ammonites. In a similar way, the Deuteronomist defines the influence of the spirit of YHWH on Saul's messengers in 1 Sam 19:20 and the action of the "evil spirit [from] YHWH" on Saul in 1 Sm 19:9: watteh $\hat{\imath}$ rûah JHWH rā'â 'el-šs' $\hat{a} l$. 
spirit of YHWH on Othniel, on the one hand, sets the indefinite point of God's calling in response to the call of the oppressed people (3:9), ${ }^{41}$ and on the other hand, it determines the forty-year period of his rule $(3: 10 \mathrm{~b}, 11)$. The verse $3: 10$ suggests that the spirit of YHWH supported the judge in his military activity, which resulted in the defeat of Chushan-Rishathaim, ${ }^{42}$ and then in the period of peaceful rule: watteĥ̀ 'ālājw rûah-JHWH wajjišpōt 'et-jiśrā'ēl. Such a broad perspective of the activity of the spirit of YHWH is observed only in the text about Othniel, which also distinguishes him from other Israeli leaders. The summary does not specify how the spirit of YHWH acts in the judge ${ }^{43}$ but it is limited to stating the fact of his presence in the deeds of the charismatic. The redactor of 3:7-11 focuses the reader's attention rather on the status of the office of the judge, whom God's help gives the appropriate authority and effectiveness in the military and administrative sphere. Thanks to the motif of the spirit of YHWH, the power of Othniel, followed by the rule of other judges,

41 It is worth emphasizing that the appointment of judges is not related to any external rite of granting them the spirit of God, as it happens in case of Joshua, who received rûh hokmâ the "spirit of wisdom" by imposing the hands by Moses (Deut 34:9). The extensive scenes of calling can be seen only in the Gideon cycle (6:11-23) and the Samson cycle (13:1-25). Interestingly, out of all judges, these two leaders, most forcefully question their mission, charism and moral-religious commitments, and even discourage the people from monotheistic worship (8:24-27).

42 The Deuteronomist describes the source of the effectiveness of armed operations of Othniel using the phrase wajjittēn JHWH bejādô "and YHWH gave in his hands" (3:10b). He uses it most often when he wants to depict the military actions of judges in the category of "the war of YHWH" and to emphasize His help. The information about the spirit of YHWH influencing Othniel since his appointment as a liberator (môšîa') is in the context of 3:9-10 an additional confirmation of the motif of God's interference in the war with the Arameans, and was added by the later redactor of the book.

43 A similar situation takes place in the narrative about Jephthah (11:29). In other cases $(6: 34 ; 13: 25 ; 14: 6,19 ; 15: 24)$, the influence of the spirit of YHWH on the liberator is expressed by Hebrew terms: lābaš, $p \bar{a}$ 'am and șälah. Relying on the analysis of these terms, exegetes differently define the nature of the spirit of YHWH and the nature of its influence on the judges. Some see in them allusions to the inner life and spiritual essence of God, and even the first traces of its Trinitarian aspect. Others deny the direct connection of the spirit of YHWH with the person and nature of God and do not consider it as a direct supernatural interference. They perceive the concept of the spirit of YHWH as a way of expressing the sudden surge of energy, strength and vitality, which was natural and temporal. C. Conroy, Leadership, p. 28; F. Mirguet, La représentation du divin, pp. 282-283. Regardless of these views, it must be strongly emphasized that the texts about judges clearly suggest the supernatural character of this phenomenon and stress that the undertaking and implementation of a mission given by God exceeded the human capabilities of the leaders of Israel. 
acquires in the book the status of a charism, which God gave the Israelites in a difficult period of their struggle for Canaan. The account of Othniel is the first to reveal the military, social and religious nature of the mission of the liberator, calling him šopet a "judge," but also môšria" a "liberator." This text, in the current structure of the book, plays the role of a literary and theological paradigm, becoming the reference point for the reader of the book in the assessment of the successive leaders of Israel and the traditions devoted to them. The concept of the spirit of YHWH, which inspires Othniel's actions, also associates the office of the judge-liberator with other institutions of the Hebrew Bible, for example: the war of YHWH, the rule of God's retribution, the Sinai covenant, theocracy or the generation system in Israel. The Old Testament vision of these institutions underlines in various ways the motif of the constant presence of YHWH in the history of Israel and God's cooperation with its leaders.

The theological accent is somewhat different in the narrative of Gideon and Abimelech (6:19-9:57), which is the longest collection of traditions in the Book of Judges. In this very complex literary cycle of source texts developed in the Deuteronomistic circles (see 6:1,6b-7a; 8:27b-28,32,33-35) the phrase rûah YHWH appears only once in 6:34 to illustrate the circumstances in which Abiezer's family rebelled against the coalition of the Midianites, the Amalekites and the people of the East. The syntagma rûh JHWH indicates the source of Gideon's courage (6:34). Unexpectedly he decided to lead the neighboring clans to start conscription and fighting against the invaders. The note about the activity of the spirit of YHWH, which in the theological sense of the cycle functions as the direct cause of the character's spiritual metamorphosis and the basis of his courage and faith in God's support (6:12-23,27,36-40; 8:1-3), does not belong to the original source, but is the result of its re-reading at one of the last stages of the book's redaction. The proof of it is the description of the activity of the spirit of YHWH expressed by the term lābaš "to dress, cover, cover as a garment, embrace, take over" which appears only in the Hebrew Bible (1 Chron 12:19; 2 Chron 24:2).The influence of the spirit of YHWH: werûh JHWH lābšâ 'et-gid'ôn in the account of Gideon is based on taking the full control (covering as if with a cloak or coat) the mind, spirit, will and body of the judge, and supernaturally equipping it with everything that was necessary to carry out effective military action. Compared to the account of Othniel (3:10), the most immediate context of 6:34 does not refer the presence of the spirit of YHWH to all Gideon's activities as a judge, but only to the conscription that Joash's son initiated within the clan of Abiezer and the generations of Manasseh, Asher, Zebulun and Naphtali (6:34-35). The spirit of YHWH who inspires and motivates to action no longer appears at any stage of the military 
mission of the judge $e^{44}$ or during a period of peaceful government (8:22-32). The influence of the spirit of YHWH on the judge is presented by the author of the gloss in the form of metaphor referring to "dressing or clothing," in order to create the image of supernatural and invincible power, knowledge, courage, sacrifice, which restored in the person endowed with the charism faith in himself, trust in the effective support of YHWH, removed fear of the enemy and encouraged to the immediate fulfillment of God's mission $(6: 14,16)$. The redactor of the Gideon cycle also stresses the supernatural genesis and effects of God's gift giving examples of the extent of the Midianite persecution (6:1-7a) and the constant motif of the judge's anxiety and unbelief (6:11-7:15), which cannot be encountered in other parts of the book. In the current structure of the cycle, spiritual dilemmas of the judge are manifested in a meeting with the Messenger of YHWH (6:13-18), in the face of God's command to remove the idolatrous worship from the house of Joash (6:27) and the eminent battles against the Midianites $(6: 36-40 ; 7: 9-15)$. They somehow prepare the room for the action of the spirit of God, whereas the metamorphosis of Gideon's attitude and victory over the Midianite coalition are clearly shown as the fruit of theophany and interference of YHWH (6:11-21,22-23,25-26,36-40; 7:2-7,9-15), and, above all, the result of the activity of His spirit (6:34). This activity is considered to be a sign of God's salvific presence (see 3:10), though, in contrast to 3,7-11, it is directly related to the military sphere of the judge's actions.

The last fragment in this group of texts including the phrase rûah-YHWH is the verse 11:22 incorporated in the story of Jephthah (10:6-12:7). It informs about the interference of the spirit of YHWH into his life in the context of armed confrontation with the Ammonites. The passage is in the form of a summary describing Jephthah's final preparations for the battle and starts with the redactional gloss of the spirit of YHWH: watte hî 'al-jiptāh rûah -JHWH "and YHWH was above Jephthah." ${ }^{45}$ The form and content of this gloss evokes a similar text from the summary about Othniel (3:10), which determines its editorial and

44 At every stage of the narrative of Gideon's war with the Midianite coalition, YHWH is shown as the main initiator of events and the ultimate cause of the persecution and liberation of the Israelites $(6: 1,8,11-23,25-26,40 ; 7: 2-7,9-11,22)$. In this sequence of texts, the phrase "spirit of YHWH" appears only once (6:34).

45 Both the terminology and the content of this phrase do not reflect the style and theology of the source about Jephthah. It returns in 3:10 almost in the same form, in the passage of the influence of the evil spirit on Saul: wattehî rûah JHWH rā' $\hat{a}$ 'el-šà' $\hat{u} l$ "and the evil spirit [from] YHWH came upon Saul" (1Sm 19:9) and in the description of prophetic activity the spirit of God on his messengers: watteĥ̀ 'al-mal'ăkê ša'ûl rûh 'ẹlōhîm wajjitnabbe' $\hat{u}$ "and the spirit of God came upon Saul's messengers, so that they prophesied" (1 Sam 19:20). For this reason, its presence in 11:29 should be associated with theological 
exclusively theological nature. In this part of the narrative, the redactor of the source material about Jephthah stressed the historico-salvific aspect of the events depicted by presenting the intervention of the spirit of God. Thus he wished to suggest to the reader that the logistic and military actions of the judge interpreted in the key of the war of $\mathrm{YHWH}$, and their course and ending (the defeat of the invader) are attributed to the salvific presence of God in the history of Israel. Like the story of Gideon, the cycle on Jephthah suggests that the time of the action of the spirit of YHWH was limited only to the military activity of the judge. The preceding context of the political confrontation between Jephthah and the elders of Gilead (10:18-11:11) and the king of Ammon (11:12-28) and the following context, which informs about his controversial vow (11:30-31:34-40), only confirms a theological interpretation of the events described. Recounting the events from the life of Jephthah, the text of the saga still points to God, who first punishes the unfaithful Israelites with the Ammonite oppression (10:7-9), and then hears their prayers for help and accepts penance (10:10-16). The sign of God's forgiveness is the support of Jephthah's military efforts and the defeat of the Ammonites. The redactor expresses this help of YHWH in two ways (10:6-12:7): as a note about the influence of the spirit of YHWH on the judge during his socio-political and military initiatives (10:29a) and as the formula of giving the troops of the enemy in the hands of judge by YHWH (10:32). The theological perspective of the narrative is also emphasized by the description of Jephthah's vow and the heroic attitude of his daughter, who praises the salvific presence of YHWH in the history of Israel (10:30-31,34-40).

\subsection{The phrase "the spirit of YHWH" in the Samson cycle (13:1-16:31)}

In a different literary and theological context, rûah-YHWH returns in the Samson's saga (13:1-16:31). ${ }^{46}$ In this case, it is not about the note which is not associated with the original context of the narrative that defines or reinforces -

interpretation, applied to the source material on Jephthah by one of the Deuteronomist redactors of the book.

46 This very broad and narratively rich collection of accounts presents a colorful and frequently highly controversial figure of the most well-known representative of the Dan family in the Hebrew Bible in the climate of the socio-religious folklore of pre-monarchic Israel. The Samson cycle is the most coherent and homogeneous literary collection of traditions recorded in the book. Exegetes differently define its form, structure and genesis, but unanimously accept the source origin of its most important components, noticing the contribution of the Deuteronomist only in verses 13:1,15:20 and 16:31b. G. Moore, Judges, p. 315; R. Boling, Judges, p. 218. 
in the form of the editorial gloss - theological profile of the tradition in which it was incorporated at one of the stages of the book redaction (see 3:10;6:34; 11:29), but about a sequence of four almost identical texts duplicating the motif of the spirit of YHWH intervention (13:25; 14:6,19, 15:14). Their terminological and theological convergence, and at the same time dissimilarity from 3:10; 6:34 and 11:29 suggest that they do not come from a Deuteronomistic or a postDeuteronomistic redactor of the book. There are many indications that they belonged to the original version of the collection $13: 1-16: 31,{ }^{47}$ and certainly had been incorporated before it became an integral part of the book. The fact that the information about the interference of the spirit of YHWH into Samson's life appears four times in a two-part tradition complex of 13:1-15:20; 16:1-16:31 $1^{48}$ makes it its main motif and interprets the current version of the judge's fight with the Philistines from a theological optics. The phrase rûh YHWH appears only in the first fragment of the cycle (13:1-15:20) and is the key to the interpretation of the extraordinary events that occurred in the family of Dan from the birth and youth (calling) of Samson to his greatest success over the Philistines, when he killed as many as a thousand enemies (15:9-19) with a primitive tool. Thanks to such a distribution of the YHWH's rûah formula, Samson's story gains a strong theological profile, and he becomes the only potagonist in the Hebrew Bible that the spirit of YHWH accompanies in almost all his life. In addition, Samson is the first commander of Israel (šōpet from the very beginning is associated with the spirit of YHWH. Immediately after him, Saul and David are presented in a related theological perspective. They both will be endowed with the spirit of YHWH and will first perform the

47 Comparing the folkloristic background of the original source, which links Samson's courage and physical strength to his long hair, the idea of the spirit of YHWH (13:25; $14: 6,19 ; 15: 14)$ and angelophany revealing the divine origin of Samson's mission and bravery (nazirite in 13:5), it should be assumed that the phrase in 13:25, and perhaps the other three $(14: 6,19 ; 15: 14)$, are the fruit of the theological elaboration of the folk anecdote (military saga) about the hero from the Dan family. The redactor of the cycle gave the original content of the saga a theological overtone, expanding it to the scene 13:2-24 and a description of the activity of the spirit of YHWH (13:25). At the later stage of the cycle's redaction, the same redactor or a Deuteronomistic editor of the book (historiography Josh.-2 Kings; see the same way of describing the activity of the spirit of YHWH in 14:6,19; 15:14 and $1 \mathrm{Sm} 10: 6,10 ; 11: 6 ; 16: 13 ; 18: 10)$, added the next three phrases in key points of the first part of Samson's history (13:1-15:20).

48 Such a division of the cycle is determined by a similar-sounding formula which closes the rule of Samson as a judge in 15:20 and 16:31b: wajjišpōt 'et-jiśrā'él bîmê pelištîm 'eśrîm šānâ. 
function of the socio-military leader (nägîd) and then the king (melek) (see $13: 25 ; 14: 6,19 ; 15: 14 ; 1$ Sm 10:6,10, 11:6; 16:13).

The fragment (13:1-16:31) shows two stages in Samson's life (see 15:20; 16:31b). The first one initiates the divine announcement of the birth of the Nazirite and liberator from an infertile woman (13:5) communicated in the supernatural atmosphere of angelophany (13:2-24), and ends with a description of its implementation, recalling the series of victories of Danite over the Philistines (14:1-15:20). The second stage is the process of gradual fall of the judge ended with a humiliating personal disaster and then death (16:1-31). As indicated above, the motif of the presence and activity of the spirit of YHWH appears only in the first part of Samson's story ${ }^{49}$ and is illustrated only by means of the rûa JHWH formulas $(13: 25 ; 14: 6,19 ; 15: 14)$ bearing the appropriate description of God's influence. From these texts, only the first one is distinguished in terms of terminology, which suggests a different origin and role than it plays in the theological structure of the cycle now. The verse 13:25 with the formula rûh JHWH closes the first stage of the cycle, reporting the promises of the Messenger of YHWH regarding the barren wife of Manoah and the deliverance of Israel (13:2-23), as it is part of the summary describing their fulfillment (13:24-25). The content of the verse: wattāhel rûah JHWH lepa "ămô "the spirit of YHWH began to stir him" differs from the similar traditions of Othniel, Gideon and Jephthah with the historico-salvific perspective through which the redactor of the cycle decided to show the intervention of God. The verb hâlal closely links the presence of the spirit of YHWH to the birth of the boy, and through it to the angelophany which dominate the entire period of Samson's growing up in the family land (13:24-25). In this way, the charism of the judge gains the status of a personal and permanent gift of God, which is closely related to the hero, his clan and region, and not only to a specific military mission, as was the case with Othniel, Gideon and Jephthah. The influence of the spirit of YHWH is associated with the idea of God's blessing, which guarantees the constant and positive development of the young man until the mission entrusted to him is undertaken (13:24b). Its specific character is defined by the $p$ ' $m$ root "to induce, force, push, disturb, bother, excite". The meaning of this term suggests a constant (long-lasting) God's initiative, which first prompted the young man to act in accordance with the will of YHWH (the initiation of conflict with the Philistines and initiation of the liberation process, cf. 14:4), and then guaranteed their effectiveness. At the same time, the

49 It is worth emphasizing that the second part of the cycle (16:1-31) narrates the circumstances in which the Danite temporarily lost God's charism (physical strength), which was his own fault, and thus provoked his personal defeat (16:1-21). 
$p^{\prime} m$ root suggests constant resistance and disregard of the charism by the judge (see $14: 5,8-9 ; 15: 15,16: 1)$, which is the cause of his defeat $(16: 4-21) .{ }^{50}$ The formula rûh JHWH in 13:25 concentrates on the figure of the judge. It emphasizes divine origin of Samson's mission and its charismatic dimension (the gift of YHWH to the oppressed people), and at the same time the unbelief and recklessness of the judge, which provoke only a partial implementation of his plan of the liberation of Israel.

The first part of the Samson cycle has three more references to YHWH $(14: 6,19 ; 15: 14)$ which differ from 13,25 . The literary form and the content of these references are identical: wattișlah'äläjw rûah JHWH and in the narrative strategy they fulfill the same role of theological key which facilitates the interpretation of their immediate narrative context, showing the source and character of superhuman physical strength, fortitude and steadfastness of Danite. Their theological dimension is determined by the term saalah, which in the construction with the preposition 'ä ${ }^{51}$ signifies "to push (force, oblige) someone, penetrate (act on) someone with power, ensure effectiveness and success of an action." ${ }^{52}$ In the same way, the redactor of the cycle ${ }^{53}$ explains the sudden surge of superhuman physical strength of Samson, which saves him in three life-threatening situations: in a fight with the lion in the vineyards of Timnah (14:5-6), in the struggle with 30 Philistines in Ashkelon provoked by Samson (14:19) and a scuffle with the Philistines in Lehi (15:14-17). In the latter case, the spirit of YHWH is behind two demonstrations of the supernatural physical strength and determination of the judge, such as freeing himself from chains (15:14) and defeating 1,000 Philistines using the jawbone of a donkey (15:15-17). In case of Samson's heroic deeds, the power coming from the spirit of $\mathrm{YHWH}$ always has an individual dimension and only indirectly refers to Israel. Unlike previous judges, the son of Manoach never acts to defend the

50 The drama of Samson's story finds a biblical analogy in the tragic story of Saul (1 Sam 9:1-31:13). Both are portrayed from the same theological and ideological perspective as leaders endowed with the charism of the spirit of YHWH for the salvation of Israel from the

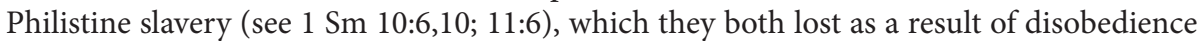
(see 1 Sm 16:14-23; 18:10; 19:9). A Deuteronomistic contrast to Samson and Saul is David, who also enjoys the gift of the spirit of YHWH (1 Sam 16:13) and completes the work of delivering Israel from the oppression of the Philistines (2 Sm. 5:17-25).

51 The same formulas in $1 \mathrm{Sm}$ are related to the preposition 'el (1 Sm 16:13; 18:10).

52 L. Koehler, W. Baumgartner, The Hebrew and Aramaic Lexicon, pp. 1025-1027.

53 Due to the terminological and theological affinity of the texts $14: 6,19 ; 15: 14$ and $1 \mathrm{Sm} 10: 6,10 ; 11: 6 ; 16: 13 ; 18: 10$, it may be assumed that they are part of the same theological re-reading that a Deuteronomistic or post-Deuteronomistic redactor applied to the traditions of Samson, Saul and David. 
oppressed Israelites and does not lead the army to wage a war against the invaders. His clashes with the Philistines have the character of a private conflict and are presented in the source material as a result of the adventurous lifestyle of the judge. ${ }^{54}$ Traditions about Samson gained the theological and pan-Israeli subtext only as a result of the two-stage theological revision performed first by the redactor of the cycle 13:1-16:31 (the phrase rûh JHWH in 13:25), followed by the Deuteronomistic or post-Deuteronomistic redactor of the book or the entire Josh-2 Kings collection (see 1 Sm 10:6.10; 11:6; 16:13; 18:10), which included the glosses with the phrase rûa JHWH in 14:6,19 and 15:14. Thanks to this theological elaboration, the reader of the current version of 13:1-16:31 perceives Samson not only as a local hero who relying on his superhuman strength and courage wages a private war against the Philistines, but as an appointed by God and supported by His spirit judge and a liberator who initiated one of the longest and most representative wars of Israel in the Hebrew Bible (Judg. 13:1-2 Sm 5:25).

Summing up the analysis of $3: 10 ; 6: 34 ; 11: 29 ; 13: 25 ; 14: 6,19 ; 15: 14$, it should be noted that the texts with the rûh-JHWH formula throw some light on the question of reconstructing the process of redaction of the tradition concerning judges and allow to define their narrative structure and theological profile. Relying on the conducted research it can be said that the idea of ruah-JHWH in the Book of Judges corresponds to the general concept of the spirit of YHWH in other passages of Deuteronomic historiography. The syntagma rûah JHWH always appears in the context of God's salvific activity focused on the release of the Israelites from the oppression of strangers. ${ }^{55}$ In 3:7-16:31, the addressees of the action of the spirit of YHWH are only šoptîm "judges" (liberators). ${ }^{56}$ Their

54 The conflict of Samson with the Philistines gains a social (reference to Israel) and theological (the idea of the war of YHWH) aspect only through later glosses, e.g. texts 13:1, $2-25 ; 14: 4$. The original saga of Manoach's son did not mention the oppression of Israel, but even informed about the collaboration of Judah with the Philistines (15:9-14) and showed a strictly private nature of the offensive actions of the judge, even in the face of death (16:28).

55 In the same vein, rûah appears in 9:23. The activity of the "spirit of discord" which God sent between Abimelech and the Shechemites was intended to lead to their conflict and defeat, and ultimately to the end of the wicked rule of Gideon's son and the restoration of peace and social order in Israel.

56 In Josh-2 Kings rûah JHWH also affects kings (1 Sm 10:1-10; 16:13-15) and prophets (1 Kings 18:12; 2 Kings 2:8-15), but never priests. The image of a charismatic judge acting by the power of God's spirit is based on other theological foundations than the image 
action is connected with God's calling (theophany) or social choice (11:10-11), takes place in the religious context of the war of YHWH $(3: 9 ; 6: 11-27 ; 11: 30$ $33,36 ; 13: 2-24)$, and its effects affect the entire Israeli community. The spirit of YHWH influences the person chosen by God in a real (visible, natural) form, and also through a supernatural interference, which causes a radical change in his life and disposition encouraging him to get involved in the process of freeing his own people. As a result, the judge obtains a universal approval from the Israelites, defeats the enemy and takes over power. The Hebrew families who are the main beneficiaries of the judge's activity gradually recognize him as a socioreligious and military leader who is supported by God and fulfils His will. In biblical terms, the verified activity of the spirit of YHWH determines the salvific presence of God and God's chosenness. This gift, although it concerned the whole Israel, was limited only to God's chosen one, it was not inherited or transmitted in an official procedure as an office or a rite to another leader or social group, as was the case, for example, with Moses and Joshua (Deut 31:1-8; 34:9; Josh 1:1-9, cf. Num 27:12-23), prophets (see 2 Kings 2:8-15) or kings (2 Sm 7-1 Kr 2; cf. Is. 11: 1-10). The theme of the spirit of YHWH is the main motif only in the Samson cycle, in other texts about judges it is important but not the essential element of the narrative. The manner and effects of its influence are described in the book in a different way, which suggests a multitude of sources and an early stage of the Old Testament pneumatology. According to the tradition of judges, the spirit of YHWH takes possession (literally, dresses, embraces, wraps) of a chosen leader (6:34), rests on him in the form of constant protection and support $(3: 10 ; 11: 29,32)$ or expressing concern incites and urges him to specific actions $(13 ; 25 ; 14: 6,19 ; 15: 14)$. In spite of terminological and theological diversity, all the texts under examination emphasize the real and supernatural, powerful, invincible and all-embracing nature of the influence of the spirit of YHWH, which adopts a favorable attitude towards the judge and Israel, and a hostile and deadly approach to their enemies.

The texts with the YHWH rûah formula lay the foundations for the Old Testament pneumatology, and their main purpose is to illustrate the stability and effectiveness of God's presence in the history of Israel. In accordance with the tradition of judges, He is behind the oppression of the Israelites (punishment for apostasy), and at the same time, appointing a brave commander, He encourages the oppressed people to fight, ensures victory over the enemy, defends the

of Moses or Joshua, although in all these cases the theme of leadership by God's will is present, the context of the threat for Israelites (the war of YHWH) and the subject of the salvific intervention of YHWH (the spirit of YHWH) (Num. 11:4-33; Deut. 31:1-8; 34:9-12; Josh. 1:1-9). 
theocratic structures in Israel $(1: 1-2 ; 6: 25-32 ; 8: 22-23 ; 10: 10-16)$ and grants peace $(3: 11,30 ; 5: 31 b ; 8: 28)$. In spite of their archaic character, the texts about the spirit of JHWH impress with their theological depth. ${ }^{57}$ Even the cursory reading of the verses $3: 10 ; 6: 34 ; 9: 23 ; 11: 29 ; 13: 25 ; 14: 6,19 ; 15: 14$ confirms that the syntagma rûh-YHWH is one of the metaphors defining the supernatural presence of God, which manifests itself to individuals, social groups and entire nations. The idea of the spirit of YHWH expresses and makes present His creative power, the power over human life, and the effective care of it through constant support, guidance and protection. ${ }^{58}$ The source material in 3:7-16:31 suggests that the rûah YHWH ('élohîm) formula is a theological paradigm depicting the action of God, the way and consequences of His supernatural presence, and in a sense also Him, and only in the second place shows the figure of the liberator and his achievements. The female gender $r h a h^{59}$ and its affinity with other feminine concepts, e.g. $n^{e} \check{s} \bar{a} m \hat{a}$ "breath" or nepeš "soul, breath, life, person." remind, on the one hand, that in the Hebrew Bible this term emphasizes the activity of YHWH rather than His person. ${ }^{60}$ On the other hand, the culturalreligious and theological background of the narrative about judges and their related traditions referring to the rûah YHWH (ĕlōhîm) formula (1 Sm 10:6,10; $11: 6 ; 16: 13,14,15,16,23 ; 18: 10 ; 19: 9,20,23 ; 2 S m$ 23:2; 1 Kings 22:24; 2 Kings 2:16) suggests that the idea of the spirit of YHWH should not be reduced only to the category of external manifestations of God's activity, but rather to be closely linked to His supernatural nature. In these texts the rûah YHWH formula expresses the spiritual and material power of God, His wisdom and strength manifested in the concrete salvific will towards individuals and nations. The invocation and sometimes even the depiction of the interference and influence of the spirit of YHWH on the attitude of judges presented by Deuteronomists, in the final perspective always indicates the transcendental personality of God,

57 W. Hildebrandt, Old Testament Theology, pp. 104-109; C. Westermann, Geist im Alten Testament, pp. 223-230; R. Idestrom, The Spirit in the Old Testament, pp. 127-133.

58 The redactor of the book understands the idea of the spirit of YHWH in the theocratic way as a method of manifesting the will of God and realizing his salvific plan for Israel in the context of the war of YHWH. R. Smend, Yahweh War, pp. 26-28; J. Walvoord, The Holy Spirit, p. 152.

59 W. von Soden, Der Genuswechsel bei rûah, pp. 57-63.

60 R. Albertz, C. Westermann, rûah, spirit, p. 1211. An example of this interpretation is the passage from 1 Kings 22:22-23 where rûah šeqer the "spirit of lies" in the mouths of the prophets of Baal, who is YHWH - according to the suggestion of a member of his court (also known as rûah) - leads to the fall of Ahab. 
which is the source and essence of His action. ${ }^{61}$ According to this interpretation, the syntagma rûah YHWH can be considered as an Old Testament type of God personification, an emanation of His spiritual and transcendent nature that does not fall into the human senses itself, but can be observed through supernatural phenomena of nature $(6: 36-40 ; 15: 14,19)$, unpredictable and inexplicable chain of events $(3: 10 ; 7: 9-15,22 ; 9: 23-57 ; 11: 29-33)$ or manifestations of superhuman strength, courage and emotions of the characters in the narrative $(13: 25 ; 14: 6,19$; 15:14-17). In the book, the idea of the spirit of YHWH is an original manner of demonstrating God's control over history, and at the same time a theological form of expression of His justice and mercy towards the Israelites and other peoples. The gift of the spirit of YHWH authorizes the position and mission of judges in the eyes of the people (cf. Num 11:24-29) inclining them to obedience and cooperation, it changes the painful course of events, breaks the power of enemies, overcomes the weakness, ${ }^{62}$ fear and disbelief of the pre-monarchic leaders, restores disrupted justice and introduces peace.

Describing the successive liberators endowed with the spirit of God, the redactors of the book do not focus on the spectacular nature of the influence but on the divine provenance of this power and its consequences, ${ }^{63}$ the only exception being the original part of the Samson saga (14:1-15:20). The theme of the spirit of YHWH is most frequently emphasized by the historico-salvific subtext of the reported events, showing the power of God against the background of the powerlessness of the people and the leader. Each time the gift of the spirit of YHWH leading to the enemy's defeat is presented it is not a response to the close and loyal relationship of the Israelites to YHWH, but as a result of God's forgiveness and pity for the unfaithful and humiliated people. The judges themselves do not betray their charism and mission before the peo-

61 Some believe that the spirit of YHWH is the transcendental emanation of the person of YHWH, through whom He exercises control over the world and people. D. Block, The Prophet of the Spirit, pp. 48-49; A. Johnson, Israelite Conception of God, p. 36. The creative power of YHWH towering over the elements of nature, enemies and all creatures whose image is nišmat rûa'appô "breath, wind of His nostrils," i.e. eastern wind or western wind (cf. Ex 10:19; 14:21), in Josh-2 Kings it is emphasized by the hymn of David (2 Sm 22:16).

62 The theme of confronting of the spirit of YHWH with unbelief and sin of the charismatic is emphasized especially in the traditions of Gideon (6:11-8:27), Jephthah (11:1-3:3031) and Samson (14:1-16:31a).

63 The redactor of the Elijah and Elisha cycles, who emphasizes the supernatural effects of the influence of God's spirit on the prophets, differs slightly in this regard (1 Kings 18:12; 2 Kings 2:16). Remaining under the influence of the spirit of $\mathrm{YHWH}$, the judges do not have such experiences, they do not transmit His will in the form of oracles, and at most share their faith in His support during military operations $(7: 15 ; 11: 30-31 ; 15: 18 ; 16: 28)$. 
ple, they do not invoke God's chosenness, and they do not give orders to the people in the name of the God of Israel, although some are aware of participating in the war of YHWH $(7: 15,18,20)$. Only Samson speaks loudly about his vocation and mission, but his confession does not refer to the spirit of YHWH, and its context announces a dramatic fall (16:17). Traditions about judges do not mention the internal transformation of the charismatic under the influence of the spirit of YHWH, as in the case of Saul (1 Sm 10:6), or the external rite which would call the presence of God's spirit or confirm it to the people (see 1 Sm 10: 1,10-11;16:13). ${ }^{64}$ Finally, in spite of numerous weaknesses and sins, the judges do not lose the spirit of YHWH, as in the case of the first king of Israel (1 Sm 16:14), ${ }^{65}$ and this is because it is still the period of God's theocratic rule in Israel (see $1 \mathrm{Sm}$ 8:1-22, 10:17-27).

\section{References}

Aharoni Y., "New Aspects of the Israelite Occupation in the North," in: J. Sanders, Near Eastern Archaeology in the Twentieth Century, Garden City 1970, pp. 254-267.

Albertz R., Westermann C., rûah, spirit, in: E. Jenni, C. Westermann, Theological Lexicon of the Old Testament Peabody 2004, vol. 3, pp. 1202-1220.

Amit Y., "Who Was Interested in the Book of Judges in the Persian-Hellenistic Periods?," in: D. Edelman Deuteronomy-Kings as Emerging Authoritative Books, SBL 6, Atlanta 2014, pp. 103-114.

Block, D., "Empowered by the Spirit of God. The Holy Spirit in the Historiographic Writings of the Old Testament," SBJT 1 $(1 ; 1997)$, pp. 42-61.

Block D., Judges, Ruth, NAC 6, Nashville 1999.

Block, D., "The Prophet of the Spirit. The Use of $r w h$ in the Book of Ezekiel," JETS 32 (1989), pp. 27-49.

Boling, R., Judges. Introduction, Translation and Commentary, AB 6A, New Haven 2005. Conroy C., "'Leadership' e profezia come doni carismatici," PSV 4 (1979), pp. 27-41.

Dunn, J., "Spirit, Holy Spirit," in: J. Douglas, New Bible Dictionary, Downer Grove 1996, pp. 1125-1129.

64 In the case of the first kings, the charism of the spirit of YHWH is closely related to the office of the prophet and the rite of the anointing (1 Sm 10:1-13; 16:1-13). In the case of judges, the prophet (Deborah) only participates in the appointment of Barak, but in this situation there is no mention of the spirit of YHWH, but only God's oracle which promises victory $(4: 4-10)$.

65 The verse 16:20 does not mention taking away the rûa YHWH from Samson, but says that YHWH turned away from the judge. However, this is not a final turning back (see $1 \mathrm{Sm} 28: 15-19 ; 31: 1-13)$. The epilogue of the saga speaks of Samson's superhuman strength, suggesting to the reader a return of God's power in response to the plea of the judge $(16: 28-30)$. 
Falkenstein A., von Soden W., Sumerische und akkadische Hymnen und Gebeten, Zurich 1953.

Gesenius W., Kautsch E., Hebräische Grammatik, Leipzig 1909.

Gillmayr-Bucher S., "Memories Laid to Rest. The Book of Judges in the Persian Period," in: D. Edelman Deuteronomy-Kings as Emerging Authoritative Books, SBL 6, Atlanta 2014 pp. 115-132.

Guillaume P., Waiting for Josiah: The Judges, JSOT.S 385, Sheffield 2004.

Haag H., "Gideon - Jerubbaal - Abimelek, “ ZAW 79 (1967), pp. 305-314.

Hildebrandt W., An Old Testament Theology of the Spirit of God, Peabody 1995.

Idestrom R., "The Spirit in the Old Testament: a Review of an Old Testament Theology of the Spirit of God by Wilf Hildebrandt," JPT 7 (1999), pp. 127-133.

Johnson A., The One and the Many in the Israelite Conception of God, Cardiff 1961.

Die keilalphabetischen Texte aus Ugarit einschliesslich der keilalphabetischen Texte ausserhalb Ugarits (eds. M. Dietrich - O. Loretz - J. Sanmartin), AOAT 24; Neukirchen-Vluyn 1976.

Knauf E., Midian, Wiesbaden 1989.

Koehler L., Baumgartner W., The Hebrew and Aramaic Lexicon of the Old Testament, Leiden 2000.

Mayes A.D., "Israel in the Period of the Judges," SBT 29, London 1974.

Mirguet F., La représentation du divin dans les récits du Pentateuque, VT.S 123, Leiden 2009.

Moore G., Critical and exegetical Commentary on Judges, ICC; Edinburgh 1989.

Morenz S., Gott und Mensch im alten Ägypten, Leipzig 1964.

Lindars B., "Gideon and Kingship," JTS 16 (2; 1965), pp. 315-326.

Pelt van M., Kaiser W., Block D., rûah, in: G. Botterweck, H. Ringgren, Theological Dictionary of the Old Testament, Grand Rapids 2004, pp. 1073-1078.

Person R., “The Deuteronomic School. History, Social Setting, and Literature," SBL 2, Atlanta 2002.

Reymond, P., rwḥ, in: J. Soggin, Dizionario di ebraico e aramaico biblici, Roma 1995, p. 386.

Reymond, P., rûah, in: J. Soggin, Dizionario di ebraico e aramaico biblici, Roma 1995, pp. 386-387.

Richter W., “Zu den Richtern Israels," ZAW 77 (1; 1965), p. 40-72.

Scerbo, F., rûah, Dizionario ebraico e caldaico del Vecchio Testamento, Firenze 1912, pp. 344-345.

Smend R., Yahweh War and Tribal Confederation, Nashville 1970.

Soden von W., "Der Genuswechsel bei rûah und das grammatische Geschlecht in den semitischen Sprachen," ZA 5 (1; 1992), pp. 57-63.

Steinmann A., "The Mysterious Numbers of the Book of Judges," JETS 48 (2005), pp. 491-500.

Tengström S., rûah, G. Botterweck, H. Ringgren, Theological Dictionary of the Old Testament, Grand Rapids 2004, vol. XIII, pp. 365-396.

Walvoord J., The Holy Spirit, Grand Rapids 1965.

Westermann C., "Geist im Alten Testament," ET 41 (1981), pp. 223-230. 